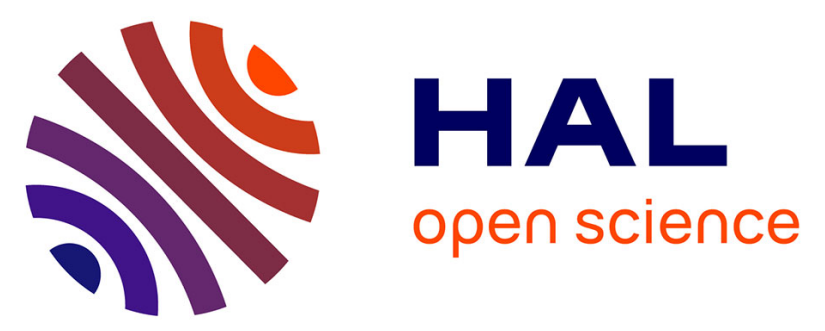

\title{
Evaluation of a RT-PCR based routine screening tool for the detection of disseminated epithelial cells in the bone marrow of breast cancer patients
}

Sven Becker, Graziella Becker-Pergola, Malgorzata Banys, Natalia Krawczyk, Diethelm Wallwiener, Erich Solomayer, Christina Schuetz, Tanja Fehm

\section{To cite this version:}

Sven Becker, Graziella Becker-Pergola, Malgorzata Banys, Natalia Krawczyk, Diethelm Wallwiener, et al.. Evaluation of a RT-PCR based routine screening tool for the detection of disseminated epithelial cells in the bone marrow of breast cancer patients. Breast Cancer Research and Treatment, 2008, 117 (2), pp.227-233. 10.1007/s10549-008-0174-3 . hal-00478263

\section{HAL Id: hal-00478263 https://hal.science/hal-00478263}

Submitted on 30 Apr 2010

HAL is a multi-disciplinary open access archive for the deposit and dissemination of scientific research documents, whether they are published or not. The documents may come from teaching and research institutions in France or abroad, or from public or private research centers.
L'archive ouverte pluridisciplinaire HAL, est destinée au dépôt et à la diffusion de documents scientifiques de niveau recherche, publiés ou non, émanant des établissements d'enseignement et de recherche français ou étrangers, des laboratoires publics ou privés. 


\title{
Evaluation of a RT-PCR based routine screening tool for the detection of disseminated epithelial cells in the bone marrow of breast cancer patients
}

\author{
Sven Becker · Graziella Becker-Pergola - Malgorzata Banys • \\ Natalia Krawczyk · Diethelm Wallwiener • Erich Solomayer • \\ Christina Schuetz $\cdot$ Tanja Fehm
}

Received: 28 May 2008/Accepted: 25 August 2008/Published online: 14 September 2008

(C) Springer Science+Business Media, LLC. 2008

\begin{abstract}
Purpose Numerous studies have shown that the presence of clinically occult disseminated tumor cells (DTC's) in the bone marrow (BM) of breast cancer patients is associated with an unfavourable clinical outcome. Immunocytochemistry (ICC) remains the gold standard for their detection. While assays based on RT-PCR are available, they have not been used for routine detection of DTC's. Methods To assess the quality of the assay, we performed a direct comparison of DTC detection rates in a large cohort of 385 patients using both standardized ICC and real-time RT-PCR protocols. Correlation rates were assessed, and results were compared with clinical data. Results A significant correlation between ICC and RT-PCR was observed $(P<0.01)$. Positivity rates were similar (both $35 \%$ ) and the results of both methods agreed in $73 \%$ of cases (280/385). Conclusions We describe a real-time RT-PCR based protocol for DTC-detection that has been specifically designed for routine clinical laboratory use. As such, RT-PCR has the potential to become an alternative testing method for BM evaluation in breast cancer patients.
\end{abstract}

Keywords Disseminated tumor cells . Immunocytochemistry $\cdot$ Minimal residual disease . Bone marrow $\cdot$ Breast cancer $\cdot$ RT-PCR

S. Becker $(\bowtie) \cdot$ G. Becker-Pergola $\cdot$ M. Banys ·

N. Krawczyk - D. Wallwiener - E. Solomayer .

C. Schuetz - T. Fehm

Department of Gynaecology and Obstetrics, University Hospital

Tuebingen, Calwerstrasse 7, 72076 Tuebingen, Germany

e-mail: sven.becker@med.uni-tuebingen.de

\section{Introduction}

Treatment decisions for breast cancer patients are mostly based on TNM-status, tumor grade, hormone receptor status and HER2-status [1]. Despite complete surgical resection and optimal systemic therapy a subset of patients still suffers from relapse. Patients who are at high-risk for relapse can be identified by the presence of clinically occult disseminated tumour cells (DTCs). Numerous studies, including a large pooled analysis, provide level I evidence that the presence of such cells in the bone marrow (BM) is associated with an unfavourable clinical outcome [2-5]. Currently, immuncytochemistry using pancytokeratin antibodies is the gold standard for the detection of DTCs [6]. A consensus has been published for the standardised detection of DTC's as well as the clinical implications of their detection [7]. Recently, RT-PCR based methods have been established as an alternative to ICC. Various markers were evaluated including mammaglobin and cytokeratin 19 (CK19) [8-13]. CK19 is an intermediate filament cytokeratin and stably expressed in epithelial tissues but not in mesenchymal haemopoietic cells. We have developed an assay for the detection of DTCs targeting the CK19 transcript with a real-time RT-PCR using the Light Cycler system. Our focus was the possibility of routine clinical application. 385 patients were screened over a 12 month period using both methods. Endpoint of our study was to compare ICC and RT-PCR-positivity rates.

\section{Materials and methods}

This study was approved by the University of Tübingen Ethics Committee in compliance with the Declaration of Helsinki ethical principles for medical research involving 
human subjects. After written informed consent, BM samples were obtained from 385 breast cancer patients who were treated at the Tuebingen University Breast Center (Tuebingen University Hospital, Tuebingen, Germany) over a 12 month period. $15-20 \mathrm{ml}$ of BM were aspirated from the anterior iliac crest into syringes containing heparin under local or general anesthesia using the Jamshidi technique [14]. Time of aspiration was noted on the test tube and samples arrived in our in-house laboratory within $30 \mathrm{~min}$. Samples were divided into two parts: (a) 7-10 ml were transferred into a new tube and immediately processed for RT-PCR detection and (b) 7-10 ml were set aside for subsequent ICC processing. RT-PCR-Samples were processed immediately and mixed with $50 \mathrm{ml}$ RNA/DNA Stabilization Reagent for Blood and BM (Roche Diagnostics), causing cell lysis and stabilization of nucleic acids (guanidinium thiocyanate effect). Samples were then immediately frozen at minus $20^{\circ} \mathrm{C}$ until further processing. Subsequent analysis was performed in batches of 5-10 samples.

\section{RT-PCR assay}

MRNA was extracted using the mRNA Isolation Kit for Blood and BM (Roche Diagnostics). The system uses a magnetic glass particle technology in a two step procedure and yields purified mRNA. MRNA isolation was performed according to the manufacturer's instructions and eluted in $10 \mu \mathrm{l}$ DEPC treated $\mathrm{H}_{2} \mathrm{O}$. Light Cycler One-Step RT-PCR for CK19 using the RNAMaster Hybridization Probes Kit (Roche Diagnostics) was performed and yielded a product of 309 bp. $5 \mu \mathrm{l}$ of mRNA were subjected to RT-PCR with a $\mathrm{Mn}[\mathrm{OAc}]_{2}$ concentration of $3 \mathrm{mM}, 0.5 \mu \mathrm{M}$ of each primer (primer A: AGATCCTGAGTGACATGCGAA; primer B: CCCAGCTGGGCTTCAATAC) and $0.125 \mu \mathrm{M}$ of each probe (probe A: CCCTTCAGGGGTCTTGAGATGAGCx, probe B: LCRedGCAGTCACAGCTGAGCATGAAAGCp) were used. Design and synthesis of primers and probes are specific for the CK19 gene (Tibmolbio) and avoid amplification of the CK19 pseudogene [15]. Reverse Transcription was performed at $60^{\circ} \mathrm{C}$ for $20 \mathrm{~min}$ immediately preceding the PCR (Hotstart at $95^{\circ} \mathrm{C}$ for $30 \mathrm{~s}$ and 50 cycles: $95^{\circ} \mathrm{C}$ for $1 \mathrm{~s}, 55^{\circ} \mathrm{C}$ for $15 \mathrm{~s}, 72^{\circ} \mathrm{C}$ for $13 \mathrm{~s}$ ). PCR products were then analysed using the Fit Points Method of the Light Cycler software. Specificity was ensured by a negative control of $5 \mathrm{ml}$ blood from a healthy volunteer that was included in the experiment. In addition one $\mathrm{H}_{2} \mathrm{O}$ sample was run in parallel to check for possible contamination of RT-PCR reagents and equipment. One positive control, consisting of preparations of MCF-7 cells spiked with $5 \mathrm{ml}$ blood from a healthy volunteer was included with each batch. Data analysis was performed with the LC software version 3.5 Fit Points method and results were compared to a previously established standard curve of positive control samples with a detection limit of 5 MCF-7 cells mixed with $5 \mathrm{ml}$ blood containing $3 \times 10^{6}$ PBMCs. The housekeeping gene GAPDH was amplified with specific primers (Tibmolbio) to check for RNA integrity.

Preliminary testing

RNA stability assays were performed before patient samples were analysed using direct RNA stabilisation after various time intervals. These tests showed highly time sensitive RNA degradation starting immediately after BM sampling [16]. Preceding the analysis of clinical specimens, a dilution series of tissue cultured breast cancer cells (MCF-7) cells helped to define the sensitivity of the assay of 5 tumor cell in $3 \times 10^{6}$ PBMCs and is shown in Fig. 1. One positive control consisting of RNA from 5 isolated tumor cells mixed with $3 \times 10^{6}$ PBMCs from a healthy individual was included with each patient batch in order to verify specific amplification of the CK19 gene and ensure adequate sensitivity.

Detection of CK positive cells by ICC

Tumor cell isolation and ICC detection was performed according to recommendations for the standardized detection of DTC's by the Collaborative BM Micrometastases

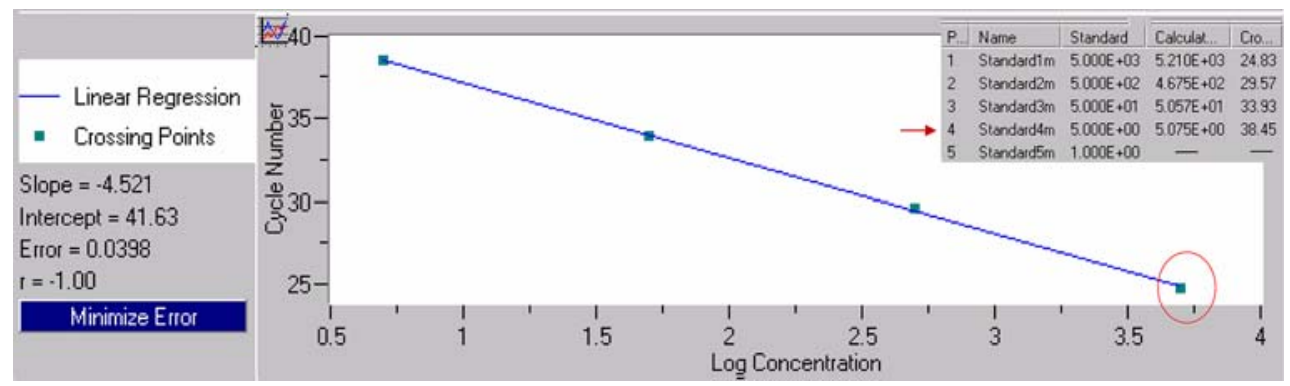

Fig. 1 Determination of sensitivity of the RT-PCR assay by Fit Points method of the Cycler Software package. A 10-fold dilution series of MCF-7 breast cancer cells $\left(5 \times 10^{3}, 5 \times 10^{2}, 5 \times 10^{1}\right.$, $5 \times 10^{0}$; squares) mixed with $3 \times 10^{6}$ PBMCs determined the sensitivity of the assay by positive amplification of the $5 \times 10^{0}$ sample (circle \& arrow). The y-axis indicates the exponential phase (cycle number) of the PCR. Slope 4.521 indicates optimal amplification of the 10 -fold dilution series 
Group [7]. BM was diluted with Phosphate Buffered Saline (PBS) and mononucleated cells were obtained by density gradient centrifugation over Biocoll (density $1077 \mathrm{~g} / \mathrm{ml}$, Biochrom). Cells were washed with PBS and-if necessary-red blood cells were lysed with Lysis buffer. Cytospins were prepared with $10^{6}$ cells using a cytocentrifuge (Hettich). Fixation of cells occurred in a $0.5 \%$ neutral buffered formalin solution for $10 \mathrm{~min}$. Automated staining was performed on the Autostainer (DAKO Cytomation) using the A45B-B3 monoclonal antibody for pancytokeratin (Mikromet) at a dilution of 1:400 and APAAP detection (Dako Cytomation). The A45B-B3 antibody is directed against common cytokeratin epitopes including the CK heterodimers 8/18 and 8/19. A positive control consisting of preparations of MCF-7 cells mixed with PBMC's was included with each batch of samples, as well as a negative control, consisting of PBMC's from healthy volunteers. In order to check for unspecific staining, isotype matched myeloma protein was included as a staining control (Sigma). For each patient $2 \times 10^{6}$ cells were analyzed on two slides. Analysis was performed on the Automated Cell Imaging System ACIS ${ }^{\circledR}$ (Chromavision). Criteria for DTC-detection were based on recommendations of the European ISHAGE Working group for standardization of tumor cell detection [6].

\section{Statistics}

Chi-squared test was used to examine the relationship between categorical variables. Statistical analysis was performed using SPSS (version 11.5). $P$-values less than 0.05 were considered statistically significant.

\section{Results}

Patient characteristics

BM samples from 385 breast cancer patients were analyzed. 305 samples were obtained at the time of surgery for primary breast cancer. Sixty-three patients had a history of breast cancer and underwent secondary BM aspiration during follow-up at our outpatient clinic. The remaining seventeen patients were diagnosed with recurrent breast cancer. Clinical data of patients are shown in Table 1.

BM analysis by ICC

135 of 385 patients (35\%) had DTC's in their BM. The number of cells ranged from 1 to 8 cells per $10^{6} \mathrm{MNC}$ 's. Figure 2 demonstrates examples of $\mathrm{CK}$ positive cells in the BM of a primary breast cancer patient. The highest positivity rates were seen in primary breast cancer patients who underwent primary systemic chemotherapy. 15 of 63 (24\%) follow up samples of breast cancer patients with no evidence of disease were DTC positive.

\section{BM analysis by RT-PCR}

The CK19 detection rate by RT-PCR was $35 \%$. Figure 3 demonstrates a typical result of CK19 positive samples obtained with the Fit Points Method of the Light Cycler version 3.5 (Roche Diagnostics). In primary breast cancer, 117 of 305 patients (38\%) were DTC positive. After

\begin{tabular}{|ll|}
\hline size & Tumor cells $>$ hematopoietic cells \\
nucleus & Nucleus enlarged \\
& Irregular chromatine structure \\
& nucleoli \\
& Nucleus/Cytoplasm Relation $>1$ \\
cytokeratin & Staining intensity variable \\
& Possible perinuclear increase of staining intensity \\
& Cytokeratin staining over nucleus \\
& Possibly cytokeratin filaments visible \\
& Cell clusters detectable
\end{tabular}

Fig. 2 Criteria for evaluation of positive DTC's in bone marrow and examples from primary breast cancer patients

Table 1 Patient characteristics

\begin{tabular}{lccc}
\hline Patients enrolled & $n=385$ & ICC positive & RT-PCR positive \\
\hline Primary breast cancer & 305 & $111(36 \%)$ & $117(38 \%)$ \\
Prior surgery/no neoadjuvant chemotherapy & 277 & $95(34 \%)$ & $103(37 \%)$ \\
Stage I & 164 & $54(33 \%)$ & $64(39 \%)$ \\
Stage II & 73 & $25(34 \%)$ & $24(33 \%)$ \\
Stage III & 30 & $13(43 \%)$ & $12(40 \%)$ \\
Stage IV & 10 & $3(30 \%)$ & $3(30 \%)$ \\
After primary systemic therapy & 28 & $16(57 \%)$ & $14(50 \%)$ \\
Recurrencies & 17 & $9(53 \%)$ & $5(29 \%)$ \\
Secondary bone marrow aspiration & 63 & $15(24 \%)$ & $12(19 \%)$ \\
Total & 385 & $135(35 \%)$ & $134(35 \%)$ \\
\hline
\end{tabular}




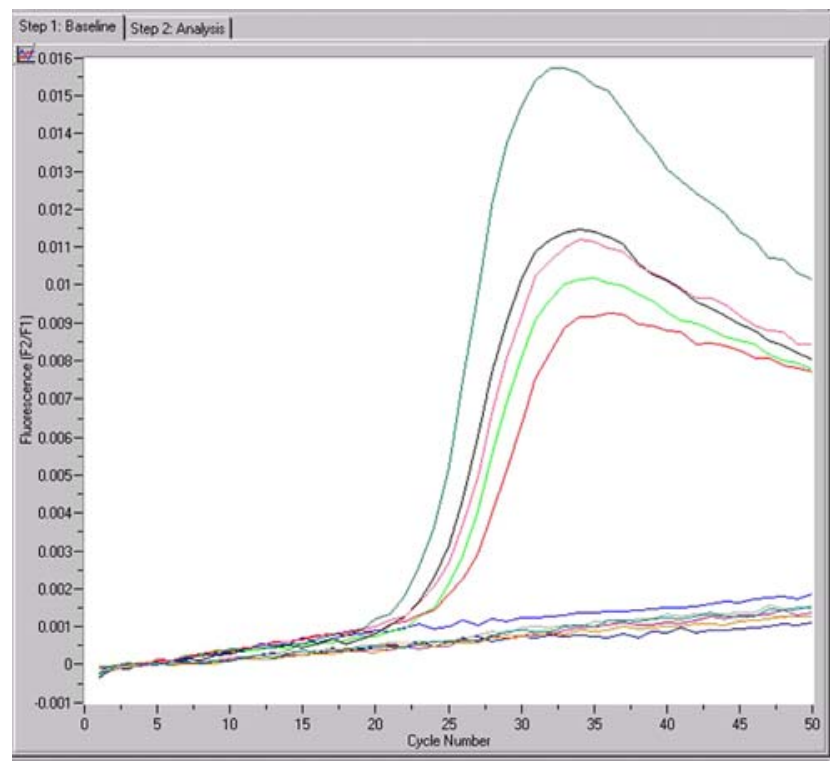

Fig. 3 Amplification curves obtained by the Light Cycler version 3.5 software package. The x-axis shows the cycle number of the PCR where amplification started. The $y$-axis shows fluorescence intensity. Five of 11 samples amplified the CK19 gene

completion of surgery and chemotherapy 12 of 63 followup patients (19\%) had DTCs detected by RT-PCR.

\section{Correlation between ICC and RT-PCR}

All 385 BM samples were analyzed by ICC and RT-PCR. The positivity rates of both methods were $35 \% .49 \%$ of the BM samples (187 of 385) were positive by at least one method. $14 \%$ of the samples were positive only by RTPCR and another $14 \%$ only by ICC. Both methods showed a statically significant correlation $(P<0.01)$.

In $73 \%$ of the patients (280 of 385 cases) identical results were obtained. 198 (51\%) patients were BM negative by both methods. Positive results by both methods were obtained in $82(21 \%)$ patients (Table 2a). In order to rule out that discordant results obtained by the two methods was the result of inferior sensitivity of the RT-PCR, we compared the number of $\mathrm{CK}+$ cells detected by ICC with PCR positivity. Table $2 b$ demonstrates that the number of detected tumor cells on ICC did not correlate with RT-PCR results $(P=0.365)$. Thus, RT-PCR correctly evaluates the BM-status for presence or absence of CK-positive cells, irrespective of their number, which would correspond to the clinical significance of the "positive" of "negative" BM-status as established by ICC.

\section{Discussion}

Over the past 15 years, the standard method of detection of disseminated tumor cells (DTCs) in the BM of breast cancer patients has been immunocytochemistry (ICC). This method has shown that DTCs are correlated independently with early disease relapse and decreased survival [17, 18]. DTC's have the potential to become targets for new therapeutic modalities, which would make routine evaluation of the BM-status an important aspect of breast cancer care. Recent efforts to standardize the ICC-approach underline its growing clinical relevance and the need for an accurate and generally accepted assessment of BM-status [7]. While ICC has emerged as the method of choice for DTCdetection, it has not been without criticism. Differences of detection rates between research groups using ICC have been attributed to the use of different cell preparation techniques, different antibodies as well as different cytomorphologic diagnostic criteria. The most consistent results have been obtained with the A45B-B3 antibody. Recent consensus meetings have recommended using this antibody and introduced standardized technical and diagnostic criteria [7]. Another problem has been the subjective aspect of cytologic evaluation. Furthermore the implementation of BM-ICC into routine clinical practice is labor intensive and costly. Efforts continue to provide an alternative, both from a methodological as well as from a logistic point of view. The focus of interest has been RT-PCR. Different research groups have established RT-PCR-protocols for the detection of DTCs [19-25].
Table 2 Positivity rates obtained by ICC and RT-PCR

\begin{tabular}{|c|c|c|c|c|}
\hline & RT-PCR negative & RT-PCR positive & Total & \\
\hline \multicolumn{5}{|l|}{ (a) } \\
\hline ICC Negative & $198(51 \%)$ & $55(14 \%)$ & $253(65 \%)$ & \\
\hline ICC Positive & $53(14 \%)$ & $82(21 \%)$ & $135(35 \%)$ & \\
\hline Total & $251(65 \%)$ & $134(35 \%)$ & $385(100 \%)$ & \\
\hline \multicolumn{5}{|l|}{ (b) } \\
\hline $1 \mathrm{CK}+$ Cell ICC & $24(46 \%)$ & $28(54 \%)$ & $52(100 \%)$ & \\
\hline $2 \mathrm{CK}+$ Cells ICC & $12(32 \%)$ & $26(68 \%)$ & $38(100 \%)$ & \\
\hline$\geq 3 \mathrm{CK}+$ Cells ICC & $17(38 \%)$ & $28(62 \%)$ & $45(100 \%)$ & \\
\hline Total positive ICC & $53(39 \%)$ & $82(61 \%)$ & $135(100 \%)$ & $P=0.365$ \\
\hline
\end{tabular}


Table 3 Comparison of RT-PCR and ICC

\begin{tabular}{|c|c|c|c|c|c|}
\hline & Smith et al. [26] & Benoy et al. [8] & Schroder et al. [27] & Schoenfeld et al. [28] & Becker et al. [16] \\
\hline Total $n$ both tests performed & 133 & 25 & 31 & 65 & 385 \\
\hline Blood/bone marrow & Blood & Bone marrow & Blood & Bone marrow & Bone marrow \\
\hline M status patients & $\mathrm{M}+$ & $\mathrm{M}+$ & M0 & M0 & M0 \\
\hline Positivity rate RT-PCR CK19 & $50 \%$ & $80 \%$ & $50 \%$ & $35 \%$ & $35 \%$ \\
\hline Positivity rate ICC $\mathrm{pCK}$ & $42 \%$ & $63 \%^{\mathrm{a}}$ & $0 \%$ b & $22 \%$ & $35 \%$ \\
\hline Same result both methods & $71 \%$ & $75 \%$ & $67 \%$ & $74 \%$ & $73 \%$ \\
\hline Correlation ICC/PCR & kappa 0.43 & $P<0.0001$ & n.a. & n.a. & $P<0.001$ \\
\hline Sensitivity RT-PCR assay & 1 in $10^{7}$ cells & 5 in $10^{7}$ cells & 1 in $10^{6}$ cells & 1 in $10^{6}$ cells & 5 in $3 \times 10^{6}$ cells \\
\hline Sensitivity ICC assay & n.a. & 1 in $10^{6}$ cells & 1 in $2 \times 10^{6}$ cells & $>1$ in $10^{5}$ cells & 1 in $10^{6}$ cells \\
\hline
\end{tabular}

a Total $(n=24)$ samples analysed

b Total $(n=149)$ samples analysed

Only few have compared their results to ICC as shown in Table 3 [8, 26-28]. RT-PCR based assays have the advantage of being highly sensitive and reproducible. They offer an objective, observer-independent way of assessing the presence of cytokeratin-bearing cells in the BM. However, due to key methodological difficulties such as the inherent instability of the CK-related RNA, its implementation remains a challenge. Our group has established a one-step real-time RT-PCR based protocol using the Light Cycler system. Our focus was the establishment of a protocol suited for clinical routine and comparable to ICC with regard to sensitivity, specificity and reproducibility. Based on our findings and those of other research groups regarding RNA-degradation we did not use any preenrichment strategy $[16,29,30]$. RNA degradation starts immediately after BM is obtained and pre-enrichment uses up additional time. Because RNA-levels of CK19-positive cells within a background of hematopoietic cells are at the threshold of detection, even small levels of degradation can lead to false negative results. Without pre-enrichment, rapid RNA stabilization ( $<30 \mathrm{~min}$ after the sample was obtained) was essential. After the addition of the RNAstabilizer, samples were stored at minus $20^{\circ} \mathrm{C}$ until further analysis, allowing sample batching, which is important for routine clinical use. The intermediate filament CK19 has emerged as the PCR-marker of choice for microdisseminated breast cancer cells [8, 31-35]. CK19 is stably expressed in epithelial tissues and tumors but not usually in mesenchymal and/or haematopoietic cells [11, 12]. Alternative markers tested by different groups have been Muc-1, urokinase type plasminogen activator receptor (uPAR), EpCAM and mammaglobin each originally considered breast cancer specific [36-38]. Some of these markers, however, have been detected in peripheral blood of a control group of healthy patients $[19,22]$ and data regarding their clinical significance remains scarce. Based on the available evidence regarding the significance of CKpositive cells in the BM, it is clear that RT-PCR would have to look at established CK-markers, too. Table 4 compares the test-specific characteristics of RT-PCR and

Table 4 Comparison of ICC and RT-PCR protocols considering aspects for routine application of protocols

\begin{tabular}{lll}
\hline & One-step RT-PCR & ICC \\
\hline Marker/Antigen & CK19 & CK8, CK18 and CK19 \\
Sensitivity & 5 MCF-7 cells/3 $\times 10^{6}$ PBMCs & 1 MCF-7 cell/10 ${ }^{6}$ PBMC's \\
Enrichment strategy & None $^{\mathrm{a}}$ & Density gradient \\
Specificity & Primers CK19 & Monoclonal PanCK antibody \\
Time needed for assay & 200 min & 300 min \\
Time for entire procedure & 1 day & 2 days \\
Cost (material only) & $€ 35,-/$ assay & $€ 13,-/$ assay \\
Subjective element & No & Yes \\
Stability of target & RNA, instable molecule & Protein, stable \\
Morphological evaluation & No & Yes \\
\hline
\end{tabular}

\footnotetext{
${ }^{a}$ Advantage: (a) RNA stabilization feasible within minutes, (b) saves time
}

b Evaluation of - negative controls (blood) were obtained from healthy blood donors-positive controls (cells from breast cancer cell line spiked with PBMCs of healthy donors) - Isotype control (MOPC21 antibody to check for unspecific staining)

${ }^{c}$ Cytospins dry overnight 
ICC. Having established an easy to use CK19-RT-PCR assay, we prospectively compared the results of our RTPCR assay with routine ICC assessment of the BM of 385 breast cancer patients. The results show a significant correlation between the RT-PCR based method and ICC, confirming previous results seen in a smaller cohort of patients [8]. Both methods rely on the detection of epithelial specific markers as indicators of epithelial derived cancer cells usually not present in the BM. While the ICC technique specifically looks for the presence of multiple proteins (CK8, 18 and 19), RT-PCR detects elevated gene expression of only CK19. CK19 is the most frequently used marker for RT-PCR detection of DTC in breast cancer patients, both in the BM and in sentinel-lymphnodes. While CK18/8 are part of the A45B-B3 antibody they have only rarely been used for DTC detection individually or as part of RT-PCR assays. The expression patterns of these epithelial cytokines are very similar to that of CK19 and they are not expected to provide more specificity than detection of the single marker CK19. In fact, the A45B-B3 antibody was initially used for the detection of non-breast cancer epithelial tumor cells. CK 18, for example, has been widely used as a marker for DTC-detection in colon cancer, but has been found to be less relevant in breast cancer.

Significant problems remain. It has been shown that haematopoietic cells potentially (though rarely) express CK19 at very low levels $[39,40]$. If sensitivity is too high, "illegitimately" expressed mRNA transcripts would be detected and specificity suffers. One way to solve this problem is to use quantitative RT-PCR, which requires a defined cut-off, above which expression of a gene is considered tumor cell specific. However, due to the heterogeneity of tumor cells, they too express CK19 at very different levels, so it has been difficult to define an exact cut off value that does not arbitrarily exclude tumor cells, reducing the value of the test overall.

So far, only one study has looked at the follow-up of patients with RT-PCR positive BM: the presence of CK19mRNA in BM was correlated with a significantly reduced overall survival [41]. Our data provides good evidence that RT-PCR might play an important part in the detection of DTC's. The test correlates well with the established standard and could serve to accumulate clinical data which then needs to be compared to clinical follow up as well. Survival data of patients recruited for this study will be available within the next 3-5 years. In summary, looking at the largest patient group to date, we report on a pragmatic and easy to use RT-PCR based assay for DTC-detection in the BM of breast cancer patients. Our results show good correlation with the existing standardized ICC. If the BMstatus of breast cancer patients becomes more important for their management, new test-options need to be explored. The RT-PCR approach is fast, can be performed in batches and requires no cytologist-evaluation. Being largely automated it can easily be implemented in established laboratory routine.

Acknowledgements This work was supported by the University of Tübingen AKF Foundation (Angewandte Klinische Forschung).

\section{References}

1. Goldhirsch A, Glick JH, Gelber RD, Coates AS, Thürlimann B, Senn HJ et al (2005) International expert consensus on the primary therapy of early breast cancer. Ann Oncol 6:1569-1583. doi:10.1093/annonc/mdi326

2. Braun S, Vogl FD, Naume B, Janni W, Osborne MP, Coombes $\mathrm{RC}$ et al (2005) A pooled analysis of bone marrow micrometastasis in breast cancer. N Engl J Med 353:793-802. doi:10.1056/ NEJMoa050434

3. Braun S, Pantel K, Muller P, Janni W, Hepp F, Kentenich CR et al (2000) Cytokeratin-positive cells in the bone marrow and survival of patients with stage I, II, or III breast cancer. N Engl J Med 342:525-533. doi:10.1056/NEJM200002243420801

4. Diel IJ, Kaufmann M, Costa SD, Holle R, von Minckwitz G, Solomayer EF et al (1996) Micrometastatic breast cancer cells in bone marrow at primary surgery: prognostic value in comparison with nodal status. J Natl Cancer Inst 88:1652-1658. doi:10.1093/ jnci/88.22.1652

5. Solomayer EF, Diel IJ, Salanti G, Hahn M, Gollan C, Schutz F et al (2001) Time independence of the prognostic impact of tumor cell detection in the bone marrow of primary breast cancer patients. Clin Cancer Res 7:4102-4108

6. Borgen E, Naume B, Nesland J, Kvalheim G, Beiske K, Fodstad $O$ et al (1999) Standardization of the immunocytochemical detection of cancer cells in BM and Blood: I. Establishment of objective criteria for the evaluation of immunostained cells. Cytotherapy 1:377-388. doi:10.1080/0032472031000141283

7. Fehm T, Braun S, Muller V, Janni W, Gebauer G, Marth C et al (2006) A concept for the standardized detection of disseminated tumor cells in bone marrow from patients with primary breast cancer and its clinical implementation. Cancer 107:885-892. doi: 10.1002/cncr.22076

8. Benoy IH, Elst H, Van der Auwera I, Van Laere S, van Dam P, Van Marck E et al (2004) Real-time RT-PCR correlates with immunocytochemistry for the detection of disseminated epithelial cells in bone marrow aspirates of patients with breast cancer. $\mathrm{Br} \mathrm{J}$ Cancer 91:1813-1820. doi:10.1038/sj.bjc.6602189

9. Datta YH, Adams PT, Drobyski WR, Ethier SP, Terry VH, Roth MS (1994) Sensitive detection of occult breast cancer by the reverse-transcriptase polymerase chain reaction. J Clin Oncol $12: 475-482$

10. Reinholz MM, Nibbe A, Jonart LM, Kitzmann K, Suman VJ, Ingle JN et al (2005) Evaluation of a panel of tumor markers for molecular detection of circulating tumor cells in women with suspected breast cancer. Clin Cancer Res 11:3722-3732. doi: 10.1158/1078-0432.CCR-04-1483

11. Bosma AJ, Weigelt B, Lambrechts AC, Verhagen OJ, Pruntel R, Hart AA et al (2002) Detection of circulating breast tumor cells by differential expression of marker genes. Clin Cancer Res 8:1871-1877

12. Gradilone A, Gazzaniga P, Silvestri I, Gandini O, Trasatti L, Lauro S et al (2003) Detection of CK19, CK20 and EGFR mRNAs in peripheral blood of carcinoma patients: correlation with clinical stage of disease. Oncol Rep 10:217-222 
13. Eaton MC, Hardingham JE, Kotasek D, Dobrovic A (1997) Immunobead RT-PCR: a sensitive method for detection of circulating tumor cells. Biotechniques 22:100-105

14. Jamshidi K, Swaim WR (1971) Bone marrow biopsy with unaltered architecture: a new biopsy device. J Lab Clin Med 77:335342

15. Ruud P, Fodstad O, Hovig E (1999) Identification of a novel cytokeratin 19 pseudogene that may interfere with reverse transcriptase polymerase chain reaction assays used to detect micrometastatic tumor cells. Int J Cancer 80:119-125. doi:10.1002/(SICI)1097-0215(19990105)80:1<119::AID-IJC22> 3.0.CO;2-X

16. Becker S, Becker-Pergola G, Fehm T, Wallwiener D, Solomayer EF (2004) Time is an important factor when processing samples for the detection of disseminated tumor cells in blood/bone marrow by reverse transcription-PCR. Clin Chem 50:785-786. doi:10.1373/clinchem.2003.025510

17. Wiedswang G, Borgen E, Karesen R, Kvalheim G, Nesland JM, Qvist H et al (2003) Detection of isolated tumor cells in bone marrow is an independent prognostic factor in breast cancer. J Clin Oncol 21:3469-3478. doi:10.1200/JCO.2003.02.009

18. Janni W, Rjosk D, Braun S (2000) Clinical relevance of occult metastatic cells in the bone marrow of patients with different stages of breast cancer. Clin Breast Cancer 1:217-225

19. Xenidis N, Perraki M, Kafousi M, Apostolaki S, Bolonaki I, Stathopoulou A et al (2006) Predictive and prognostic value of peripheral blood cytokeratin-19 mRNA-positive cells detected by real-time polymerase chain reaction in node-negative breast cancer patients. J Clin Oncol 24:3756-3762. doi:10.1200/JCO. 2005.04.5948

20. Gilbey A, Burnett D, Coleman R, Holen I (2004) The detection of circulating breast cancer cells. J Clin Pathol 57:903-911. doi: 10.1136/jcp.2003.013755

21. Ring A, Smith I, Dowsett M (2004) Circulating tumour cells in breast cancer. Lancet Oncol 5:79-88. doi:10.1016/S1470-2045 (04)01381-6

22. Silva JM, Dominguez G, Silva J, Garcia JM, Sanchez A, Rodriguez O et al (2001) Detection of epithelial messenger RNA in the plasma of breast cancer patients is associated with poor prognosis tumor characteristics. Clin Cancer Res 7:2821-2825

23. Kahn HJ, Yang LY, Blondal J, Lickley L, Holloway C, Hanna W et al (2000) RT-PCR amplification of CK19 mRNA in the blood of breast cancer patients: correlation with established prognostic parameters. Breast Cancer Res Treat 60:143-151. doi:10.1023/ A: 1006350913243

24. Aerts J, Wynendaele W, Paridaens R, Christiaens MR, van den Bogaert W, van Oosterom AT et al (2001) A real-time quantitative reverse transcriptase polymerase chain reaction (RT-PCR) to detect breast carcinoma cells in peripheral blood. Ann Oncol 12:39-46. doi:10.1023/A:1008317512253

25. Berois N, Varangot M, Aizen B, Estrugo R, Zarantonelli L, Fernandez $\mathrm{P}$ et al (2000) Molecular detection of cancer cells in bone marrow and peripheral blood of patients with operable breast cancer: comparison of CK19, MUC1 and CEA using RT-PCR. Eur J Cancer 36:717-723. doi:10.1016/S0959-8049 (99)00338-X

26. Smith BM, Slade MJ, English J, Graham H, Luchtenborg M, Sinnett HD et al (2000) Response of circulating tumor cells to systemic therapy in patients with metastatic breast cancer: comparison of quantitative polymerase chain reaction and immunocytochemical techniques. J Clin Oncol 18:1432-1439

27. Schroder CP, Ruiters MH, de Jong S, Tiebosch AT, Wesseling J, Veenstra $\mathrm{R}$ et al (2003) Detection of micrometastatic breast cancer by means of real time quantitative RT-PCR and immunostaining in perioperative blood samples and sentinel nodes. Int J Cancer 106:611-618. doi:10.1002/ijc.11295
28. Schoenfeld A, Kruger KH, Gomm J, Sinnett HD, Gazet JC, Sacks N (1997) The detection of micrometastases in the peripheral blood and bone marrow of patients with breast cancer using immunohistochemistry and reverse transcriptase polymerase chain reaction for keratin 19. Eur J Cancer 33:854-861. doi: 10.1016/S0959-8049(97)00014-2

29. Naume B, Borgen E, Nesland JM, Beiske K, Gilen E, Renolen A et al (1998) Increased sensitivity for deteion of micrometastases in bone marrow/peripheral blood stem-cell products from bresast cancer patients by negative immunomagnetic separation. Int J Cancer 78:556-560. doi:10.1002/(SICI)1097-0215(19981123) 78:5<556::AID-IJC5>3.0.CO;2-G

30. Benez A, Geiselhart A, Handgretinger R, Schiebel U, Fierlbeck G (1999) Detection of circulating melanoma cells by immunomagnetic cell sorting. J Clin Lab Anal 13:229-233. doi:10.1002/ (SICI)1098-2825(1999)13:5<229::AID-JCLA7>3.0.CO;2-Y

31. Stathopoulou A, Gizi A, Perraki M, Apostolaki S, Malamos N, Mavroudis D et al (2003) Real-time quantification of CK-19 mRNA-positive cells in peripheral blood of breast cancer patients using the lightcycler system. Clin Cancer Res 9:5145-5151

32. Ring AE, Zabaglo L, Ormerod MG, Smith IE, Dowsett M (2005) Detection of circulating epithelial cells in the blood of patients with breast cancer: comparison of three techniques. Br J Cancer 92:906-912. doi:10.1038/sj.bjc.6602418

33. Slade MJ, Smith BM, Sinnett HD, Cross NC, Coombes RC (1999) Quantitative polymerase chain reaction for the detection of micrometastases in patients with breast cancer. J Clin Oncol $17: 870-879$

34. Kruger W, Krzizanowski C, Holweg M, Stockschlader M, Kroger N, Jung R et al (1996) Reverse transcriptase/polymerase chain reaction detection of cytokeratin-19 mRNA in bone marrow and blood of breast cancer patients. J Cancer Res Clin Oncol 122:679-686. doi:10.1007/BF01209032

35. Gradilone A, Gazzaniga P, Silvestri I, Gandini O, Trasatti L, Lauro S et al (2003) Detection of CK19, CK20 and EGFR mRNAs in peripheral blood of carcinoma patients: correlation with clinical stage of disease. Oncol Rep 10:217-222

36. Pierga JY, Bonneton C, Magdelénat H, Vincent-Salomon A, Nos C, Boudou E et al (2005) Real-time quantitative PCR determination of urokinase-type plasminogen activator receptor (uPAR) expression of isolated micrometastatic cells from bone marrow of breast cancer patients. Int J Cancer 114:291-298. doi:10.1002/ ijc. 20698

37. de Cremoux P, Extra JM, Denis MG, Pierga JY, Bourstyn E, Nos C et al (2000) Detection of MUC1-expressing mammary carcinoma cells in the peripheral blood of breast cancer patients by real-time polymerase chain reaction. Clin Cancer Res 6:3117-3122

38. Ferrucci PF, Rabascio C, Gigli F, Corsini C, Giordano G, Bertolini F et al (2007) New comprehensive gene expression panel to study tumor micrometastasis in patients with high-risk breast cancer. Int J Oncol 30:955-962

39. Ko Y, Grunewald E, Totzke G, Klinz M, Fronhoffs S, GouniBerthold I et al (2000) High percentage of false-positive results of cytokeratin 19 RT-PCR in blood: a model for the analysis of illegitimate gene expression. Oncology 59:81-88. doi:10.1159/ 000012126

40. Bostick PJ, Chatterjee S, Chi DD, Huynh KT, Giuliano AE, Cote $\mathrm{R}$ et al (1998) Limitations of specific reverse-transcriptase polymerase chain reaction markers in the detection of metastases in the lymph nodes and blood of breast cancer patients. J Clin Oncol 16:2632-2640

41. Benoy IH, Elst H, Philips M, Wuyts H, Van Dam P, Scharpe S et al (2006) Real-time RT-PCR detection of disseminated tumour cells in bone marrow has superior prognostic significance in comparison with circulating tumour cells in patients with breast cancer. Br J Cancer 94:672-680 